\title{
Article \\ Grouping Ceramic Variability with pXRF for Pottery Trade and Trends in Early Medieval Southern Tuscany. Preliminary Results from the Vetricella Case Study (Grosseto, Italy)
}

\author{
Cristina Fornacelli ${ }^{1}, *\left(\mathbb{0}\right.$, Vanessa Volpi ${ }^{2,3}{ }^{(0}$, Elisabetta Ponta ${ }^{2}$, Luisa Russo ${ }^{2}$, Arianna Briano ${ }^{2}$, \\ Alessandro Donati ${ }^{3}$, Marco Giamello ${ }^{1}$ and Giovanna Bianchi ${ }^{2}$
}

check for updates

Citation: Fornacelli, C.; Volpi, V.;

Ponta, E.; Russo, L.; Briano, A.;

Donati, A.; Giamello, M.; Bianchi, G. Grouping Ceramic Variability with pXRF for Pottery Trade and Trends in Early Medieval Southern Tuscany.

Preliminary Results from the

Vetricella Case Study (Grosseto, Italy)

Appl. Sci. 2021, 11, 11859.

https://doi.org/10.3390/

app112411859

Academic Editors: Anna Galli and Letizia Bonizzoni

Received: 17 November 2021

Accepted: 8 December 2021

Published: 14 December 2021

Publisher's Note: MDPI stays neutral with regard to jurisdictional claims in published maps and institutional affiliations.

Copyright: (c) 2021 by the authors Licensee MDPI, Basel, Switzerland. This article is an open access article distributed under the terms and conditions of the Creative Commons Attribution (CC BY) license (https:/ / creativecommons.org/licenses/by/ $4.0 /)$.
1 Dipartimento di Scienze Fisiche, della Terra e dell'Ambiente, Università degli Studi di Siena, Via Laterina 8, 53100 Siena, Italy; marco.giamello@unisi.it

2 Dipartimento di Scienze Storiche e Dei Beni Culturali, Università degli Studi di Siena, Palazzo San Galgano, Via Roma 47, 53100 Siena, Italy; vanessa.volpi@unisi.it (V.V.); elisabettaponta@gmail.com (E.P.); luisarus87@gmail.com (L.R.); arianna_briano@yahoo.it (A.B.); giovanna.bianchi@unisi.it (G.B.)

3 Dipartimento di Biotecnologie, Chimica e Farmacia, Università degli Studi di Siena, Via Aldo Moro 2, 53100 Siena, Italy; alessandro.donati@unisi.it

* Correspondence: fornacelli@unisi.it

\begin{abstract}
The characterization of archaeological ceramics according to their chemical composition provides essential information about the production and distribution of specific pottery wares. If a correlation between compositional patterns and local production centers is assumed, pottery manufacturing and trade and, more generally, economic, political, as well as cultural relations between communities and regions can be investigated. In the present paper, the combined application of portable XRF and statistical analysis to the investigation of a large repertory of ceramic fragments allowed us to group the assemblage by identifying geochemical clusters. The results from the chemical and statistical analysis were then compared with reference ceramic samples from the same area, as well as with macroscopic and petrographic observations to confirm, coalesce or subdivide putative sub-divisions. The study of 141 samples from different sites located within a wide area spanning across the Colline Metallifere and the coast (Monterotondo Marittimo, Roccastrada, Donoratico, and Vetricella) provided new clues for a new interpretive archaeological framework that suggests that there was a well-defined organization of pottery manufacturing and circulation across southern Tuscany during the early medieval period.
\end{abstract}

Keywords: pXRF; PCA; pottery

\section{Introduction}

The characterization of archaeological ceramics according to their elemental composition provides essential information about the circulation and consumption of specific pottery wares in the territory [1].

In recent years, the application of pXRF analysis to archaeological issues has become attractive in many ways. It has fast acquisition times and low experimental costs, and facilitates the scanning of large repertories in a non-destructive manner. Handled and portable devices also promote the in situ analysis of a wide range of materials [2].

Despite the challenges and limitations of using portable XRF techniques with source ceramics, the use of statistical methods has helped develop a fundamental tool for discerning between different pottery samples [3]. Aside from the accuracy of both the measurement and data processing, the way the results are inferred relies on how precisely the geographic location of the source material can be defined [4]. When a precise definition of the geographic location of the source material is not possible, or the geographical range is represented by a wide and highly heterogeneous area, the analysis of the reference materials (both concerning clays and/or reference pottery samples) becomes essential for 
inferring possible ancient exchange routes $[4,5]$. Several studies have demonstrated that pXRF analyses are applicable to the provenance studies of ceramics when the geological variability of the region and/or the inclusion of reference materials are also considered [6].

In this way, pXRF produces compositions and, subsequently, clusters that can be compared with other information (such as shape, surface finish and functional typology, as well as the indications that can be obtained via traditional mineralogical and petrographic observations) to confirm, coalesce or sub-divide putative sub-divisions of the pottery assemblage under study.

In the last few years, the interdisciplinary, ERC-advanced nEU-Med project promoted an in-depth archaeometric examination of a wide repertory of different ceramic fragments and raw materials that have been obtained from the main clay sources identified in the Colline Metallifere area [7]. Within this framework, the present study aims to describe how the application of pXRF to the screening of a large repertory of ceramic fragments has supported the acquisition of new data that helps to delineate the production and circulation of pottery during the Early Middle Ages (8th-10th centuries) within the Colline Metallifere area (southern Tuscany).

The archaeological site of Vetricella is a peculiar case study, as the archaeological data collected so far (not only concerning the ceramic findings) indicate that this settlement was the center of a royal property active between the 8th and 11th centuries [8]. Thanks to the archaeological campaigns promoted by the nEU-Med project, Vetricella represents the first Italian context of a royal property that has been extensively excavated so far.

Portable XRF has been used here for a preliminary analytical survey of a wide repertory of 141 ceramic fragments from Vetricella and the nearby archeological sites of Monterotondo Marittimo, Roccastrada and Donoratico (Figure 1). The pXRF analysis is also supported by further statistical, mineralogical and petrographic analyses. The chemical investigation and the subsequent statistical grouping also aim to optimize sample selection for a further in-depth characterization of clusters and outliers via high-resolution methods. The variability of the ceramics has been determined through a new approach that is based on the unsupervised classification of chemical elements that results from handheld XRF measurements [9], albeit controlled by archaeological and typological classifications, as well as traditional mineralogical and petrographic analysis.

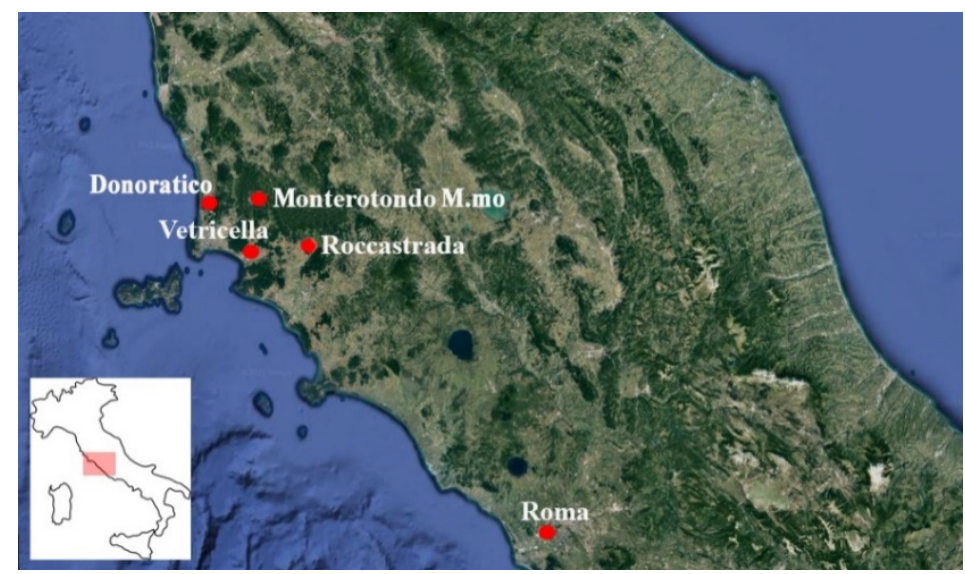

(a)

Figure 1. Cont. 


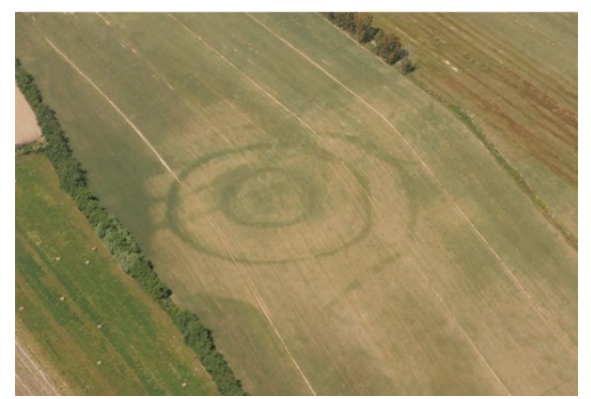

(b)

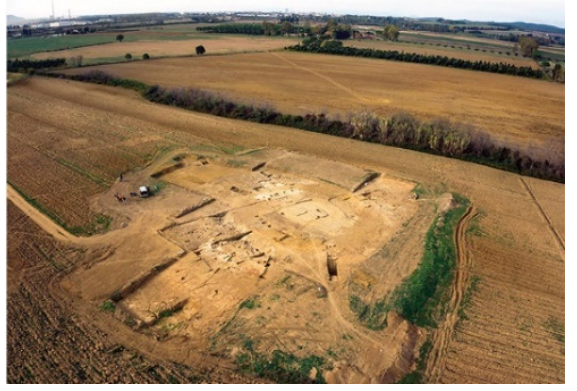

(c)

Figure 1. (a) Map of central Italy where the locations of the ceramic assemblages that have been explored in the text are reported. $(\mathbf{b}, \mathbf{c})$ The site of Vetricella.

\section{Application of Portable XRF for Ceramic Investigations: The State of the Art}

Highly sensitive benchtop analytical techniques for a chemical investigation of heterogenous samples, such as inductively coupled plasma mass spectrometry (ICP-MS), X-ray fluorescence (XRF), neutron activation analysis (NAA) and scanning electron microscopy and energy dispersive $\mathrm{X}$-ray spectrometry (SEM-EDX), have been extensively used for the geochemical characterization of both ceramic materials and clay sources [10-13]. Despite their high accuracy and precision, these methods suffer from high costs and long acquisition times, together with the partial or total destruction of the sample [4].

In the last decades, the use of non-destructive methods in conservation science has gained general acceptance [14-18], however due to the reduced sensitivity to trace elements, the use of XRF in the investigation of archaeological materials remained poor compared to more accurate analytical techniques [19].

The successful application of pXRF to the investigation of highly heterogeneous materials, such as ceramics and soils, is, however, still strongly discussed [20-28]. Central to the debate is the complex nature of the matrix itself and the quest for both high analytical precision and reproducibility $[29,30]$.

A number of dedicated analytical strategies have been proposed so far to overcome the main disadvantages that affect the application of $\mathrm{pXRF}$ to the investigation of ceramics. The analysis of homogenized powdered samples and the acquisition of multiple spots are methods used to average and assess the variations caused by the heterogeneity of the fabric (typically consisting either of a clay matrix and a mineral skeleton and/or a temper of variable particle size) and the possible presence of surface alterations (caused by firing or post-depositional conditions) or coatings [20,21,31].

A semi-quantitative estimation of the chemical concentration of each element could be achieved by the application of several calibration methods. Portable XRF spectrometers offer built-in calibration packages for a number of different substrates. Internal calibrations methods can also be adjusted by the user thanks to the measurement of certified reference materials (CRMs), or standards, which improves the accuracy of the reported concentrations within a specific dynamic range [23].

The application of built-in calibrations is, however, strongly matrix dependent, and the reduced versatility of internal software represents one of the main disadvantages to 
the use of pXRF in ceramic studies $[19,20,23,32]$. While pre-installed calibrations that are based on commercial algorithms are considered satisfactory for more homogenous substrates, the development of a material-specific calibration is strongly recommended to help users manage the complex nature of more heterogeneous materials. Previous studies, in particular, reported relative errors of around $50 \%$ for most factory calibrations, while custom standardizations typically induced a relative error of less than 10\% [32-34].

The development of an empirical calibration for ceramic studies has thus been considered mandatory for obtaining valid and solid results for an inter-instrument comparison with data extracted by the tests, or for a future evaluation of a database outside the original experiment $[21,32,35,36]$. Nevertheless, despite the high reliability of the correction coefficients that is provided by empirical matrix-matched calibrations, the accuracy of an intra-instrument comparison is not without issues, since different instruments have been demonstrated to report varying values even following the same calibration method [37]. On the other hand, if the comparability of the dataset to others could not be assured, solid empirical evidence proves the adequacy of the application of built-in calibration routines for obtaining internally consistent result for archaeological interpretations [35,38].

The validation of dedicated internal calibrations in the analysis of ceramics represents an important challenge for making pXRF more accessible. For many users, a lack of access to more sensitive analytical techniques (e.g., ICP-OES, or NAA) for collecting calibration data for the creation of a matrix-matched calibration can be highly problematic and expensive, as can the acquisition of commercial calibration standards that are suitable for unprepared archaeological samples [24].

The recent advancements in hardware and software development for pXRF led to the release of more precise internal calibrations, and recent studies have called for an overall acceptance of specific built-in calibration algorithms for the semi-quantitative characterization of archaeological materials [3,24,28,29,38,39].

Robust multivariate statistical methods have been widely and successfully applied to the analysis of large chemical databases for provenance studies and for the recognition and characterization of local ceramic production to identify possible trading activities $[4,25,40,41]$.

To better represent the high variability of a geochemical dataset, a pre-processing stage is thus required to standardize data and reduce distinctions in the magnitudes between major and trace elements $[6,42,43]$. While some recent studies have stressed the advantages of applying $\log$ ratio transformations to raw data [44-47], the use of standardized $\log 10$ data, combined with multivariate statistical methods, has been demonstrated to satisfactorily represent the fluctuations in the absolute concentrations of a geochemical dataset $[48,49]$.

Qualitative pXRF analyses are frequently used in archaeology to determine the relative composition of a substance with the main aim of detecting distinguishable elements for further provenance studies [3,36-39]. A number of recent studies explored both the potentialities and limitations of the analysis of pottery using pXRF, which has thus been proven to be feasible tool for the investigation of individual assemblages of various ceramic wares $[30,50]$.

One of the most frequently highlighted limitations of the use of pXRF in provenance studies is that is has a more restricted range of detectable elements than traditional analytical methods. Despite the fact that the sensitivity and number of elements that can be measured by pXRF devices is between 10 and 20, only a variable range of 5-10 elements are in general found to be useful. Moreover, the distinction between different ceramic groups is generally based upon elements that XRF methods are not great at detecting (e.g., rare earth elements) [6].

More sensitive analytical methods (e.g., INAA, ICP-MS, etc.) have been so far extensively used in provenance studies because they can be used as part of a high dimensional dataset (for INAA and ICP-MS, this is 23 and 19 elements, respectively), which comprehensively incorporates part of the spectrum of rare earth elements (REE), meaning that they can precisely segregate elemental groups on a microregional scale [1,51]. By contrast, most of these methods involve long analytical times, together with complex and destructive sample 
preparation. Even though the sample preparation issue could be solved by using laser ablation ICP-MS, its application to the analysis of heterogeneous materials is frequently semi-quantitative at best [35,52].

Despite the non-negligible discrepancies that are registered in the absolute elemental concentrations, non-destructive $\mathrm{PXRF}$ has been demonstrated to be able to distinguish between geochemically different ceramic pastes and identify groups in ways that closely correlate with those indicated by traditional methods [19-24]. In a recent paper [6], LeMoine provides important insights and suggestions, showing how $\mathrm{pXRF}$ and INAA produced comparative broad 'macro-provenance' groupings, with some ability of INAA to provide a more detailed sub-division of large groups.

Even though pXRF cannot substitute traditional analytical methods as a general elemental provenance-identifying procedure for ceramics, it can represent an extremely powerful alternative in cases where the internal grouping of 'closed' populations of delicate and/or highly abundant repertories is required [19]. The identification of carefully tailored measurement and processing protocols might provide good statistical results in accordance with those that are obtained through lab-based methods and can strongly support the archaeological interpretation [53].

The petrographic and microtextural investigation of selected fragments can help with identifying temper- and mineral-related variations that could influence the chemical database, as well as with evaluating various technological aspects to strengthen the interpretation of pXRF results $[3,54]$. The provenance may also be inferred from the mineralogical composition of the reference groups [13].

The characterization by $\mathrm{pXRF}$ of fragments whose provenance has been already determined by $\mathrm{OM}$ and/or traditional chemical analysis can support the definition of a database for the pXRF examination of unstudied samples from the same archives in collections where intrusive sampling is not allowed. On the other hand, the initial extensive pXRF screening of large ceramic repertories also promotes the preliminary definition of compositional clusters and outliers which can provide a selection of the most representative samples to be further investigated via more sensitive analytical methods. The in-depth characterization of selected samples, based on chemical grouping, can then help to refine the data processing by providing further indications about those elements which could properly describe the chemical dataset [5,55].

Within this framework, the present study aims to validate the great potential of pXRF to help with the investigation of a large repertory of pottery samples. In view of the results, the advantages of the application of a tailored analytical method to a set of reference samples are discussed together with some preliminary outcomes that have resulted from the analysis of samples which have an unknown provenance.

\section{Archaeological Background}

Previous archaeological studies on early medieval ceramic production in Tuscany have stressed the existence of a fragmented manufacturing base that consisted of only a few dispersed production sites until the 10th century. Within this framework, the archaeological evidence suggested that there was a local manufacture of cooking, table and storage wares, with a scattering of highly skilled ateliers being documented in some areas, including the Colline Metallifere [56-59].

The archaeological studies that have been carried out in the last few years within the framework of the ERC nEU-Med project [7] aimed to provide a more accurate chronological contextualization of the production of some of these ceramic classes between the 7th and 10th centuries. This also encouraged intense research activity that has been focused on the revision of past studies on some ceramic assemblages from different sites located within the Colline Metallifere [60-64]. In the wake of the recent advances in ceramic studies that have been promoted within the nEU-Med project, the more in-depth characterization of pottery manufacture in the Colline Metallifere area provided a solid point of comparison with the exceptional findings of Vetricella. 
Vetricella and its surrounding territory formed an important royal property that preserved its status until the end of the 11th century. Since its discovery in 2005 during an aerial archaeology survey of the wide Maremma Grossetana coastal plain (southern Tuscany), the site of Vetricella immediately claimed the attention of scholars due to its many peculiarities. In particular, thanks to the exceptional variety of findings and its peculiar location in a territory that resembled many other coastal landscapes of the early medieval western Mediterranean, at a crucial junction between the sea and the Colline Metallifere, the site of Vetricella was then identified as key site within the framework of the nEU-Med project [8].

The extensive archaeological excavations carried out at Vetricella in the last years returned a variety of indicators (numismatic, ceramic and glassy materials, together with a large amount of archaeometallurgical, archaeozoological and archaeobotanical findings). The exceptional nature of these findings, combined with a detailed investigation of the historical documents, provided clues about the definition of the site as a royal property, characterized as it was by extensive economic and productive activity dating between the 9th and 11th centuries, while evidence of an earlier occupation (7th-8th centuries) was also observed [65].

Due to the variety of findings returned at Vetricella, the integration of the archaeological research with disciplines that include geoarchaeology, archaeobotany, archaeometallurgy, physical anthropology, and physical chemistry was first of all essential to reconstructing a general history of the landscape, as well as for defining the correlations between Vetricella and the exploitation of the widely heterogeneous natural resources of the Colline Metallifere $[7,8]$.

The ceramic assemblage of Vetricella includes a large repertory of pottery belonging to different ceramic functional classes, such as cooking ware, tableware and storage products (jars, jugs, pots, bowls and small amphorae), as well as the highly skilled Forum and sparseglazed wares. The significant amount of pottery dedicated to different uses and related to well-defined stratigraphical contexts represented an optimal repertory with which to deepen the investigation into pottery production in south-western Tuscany during the Early Middle Ages.

A preliminary comparison of the ceramic assemblage returned at Vetricella with those from other sites located within the Colline Metallifere (e.g., Monterotondo Marittimo and Roccastrada) and the coast (Donoratico) allowed us to define the existence of a complex and well-organized manufacturing base that was characterized by large-scale distribution within the territory (dating back to the 7th-8th centuries and with a recognizable increase from the 9 th until the 11th centuries).

The multidisciplinary investigation then started to help us form an in-depth characterization of the ceramic assemblages as they related to different sites that are located within the broad and heterogenous Colline Metallifere area, which would in turn help us to identify possible production areas and distribution flows within the territory. The results from this study also provided new perspectives on the distribution of goods within Colline Metallifere during the 7th-11th centuries and suggested that Vetricella played a key role as a central site dedicated to the collection and re-distribution of a wide and heterogeneous range of locally produced materials.

\section{Geological Background}

The geological setting of the area is the result of a sedimentary and tectonic evolution that affected the Italian peninsula between the Oligocene and the Pliocene, and which was strongly connected to the several superimposed compressive stages that led to the formation of the nappes of the Northern Apennines [66]. The heterogenous structural and stratigraphic setting of southern Tuscany is therefore derived from different deformational processes that are related to the convergence between the Corsica-Sardinia and Apulia microplates [67] and to the following post-collisional extensional tectonics [68]. 
Between the Oligocene and lower Miocene, the compressional deformations related to the collisional episodes resulted in the development of a nappe sheet stack consisting of different paleogeographic domains.

From the late Miocene, post-collisional magmatism affected southern Tuscany and the northern Tyrrhenian Sea. The diffused acidic peraluminous intrusive bodies (Elba, Montecristo, Giglio, Gavorrano, Campiglia Marittima) and cogenetic volcanic products (rhyolites of San Vincenzo, Roccastrada, La Tolfa) originated from the intense igneous activity that today defines the so-called Tuscan Magmatic Province (TMP) [69]. The TMP consists of three main magmatic typologies (melts originating from crustal anatexis, melts resulting from the mixing of acid crustal and basic subcrustal melts, and mantle-derived melts) among which the Roccastrada rhyolite represents the most acidic term [70].

The emplacement of magmatic rocks and the related intense hydrothermal circulation led to the formation of several mineral deposits [71]. Polymetallic sulphidic deposits $(\mathrm{Cu}-\mathrm{Pb}-\mathrm{Zn}-\mathrm{Ag})$ of southern Tuscany are mainly hosted along a belt which extends from the Tyrrhenian coast towards the province of Siena.

Between the middle Miocene and the Pliocene, the occurrence of extensional tectonics and crustal thinning led to the development of sedimentary basins with significantly different tectonic and stratigraphic features [72]. The sediments filling the extensional basins formed the so-called Neo-autochthonous Complex [73], representing the uppermost post-orogenic sedimentary succession of southern Tuscany and mainly consisting of limestone breccias, fluvial conglomerates and calcareous tufa, together with lacustrine-marine (late Tortonian-Messinian), marine (Pliocene) and lacustrine-fluvial (early VillafranchianQuaternary) clays [66,72,74] (Figure 2).

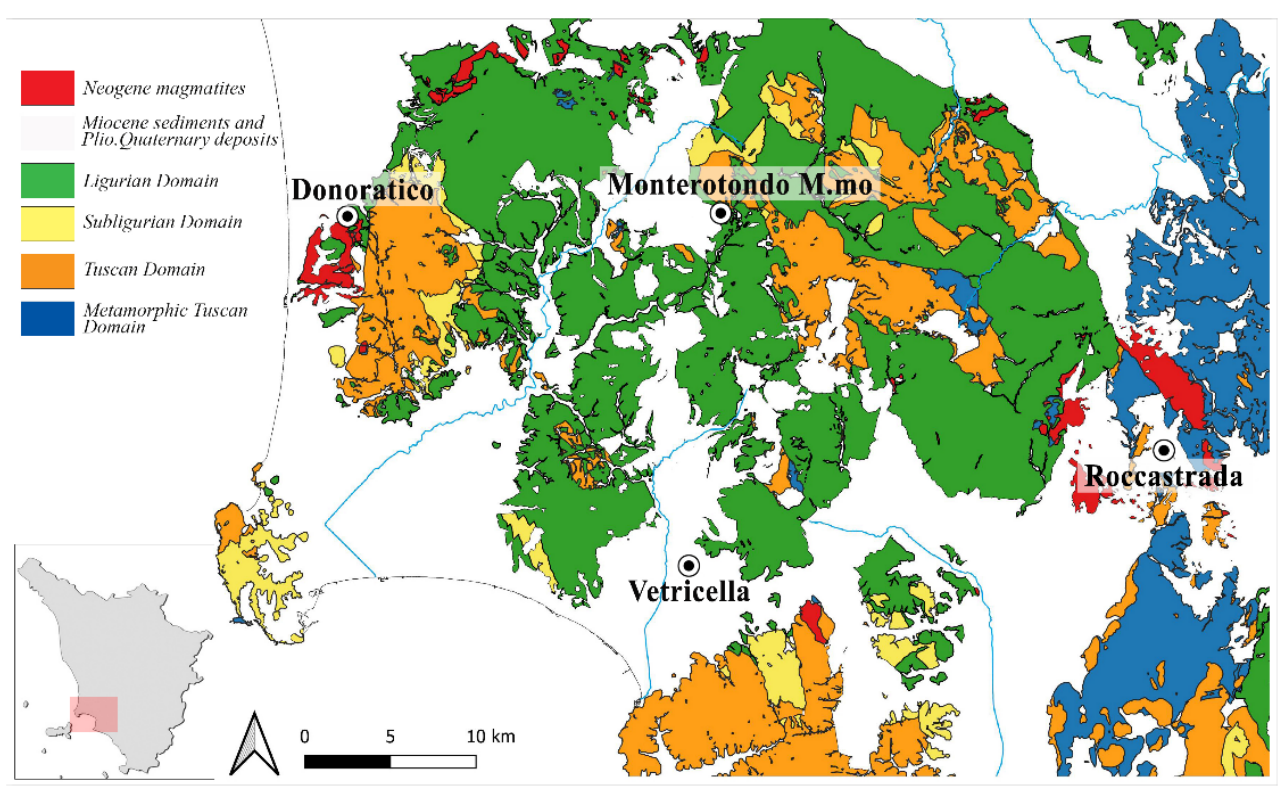

Figure 2. Geological map of southern Tuscany.

\section{Materials and Methods}

For the present study, the selected ceramic repertory from the Vetricella archaeological site includes 83 fragments (Supplementary Materials, Table S1), together with reference samples (Supplementary Materials, Table S2) consisting of 58 fragments from Monterotondo Marittimo (16), Roccastrada (13) and Donoratico (29).

The ceramic assemblage (Figure 3) consists of fine- to coarse-grained pottery for different uses (tableware, storage ware, cooking ware) which dates back to the 7th-10th centuries. Some of the samples are characterized by the presence of a $\mathrm{Pb}$-based coating on the external surface (sparse-glazed ware). 

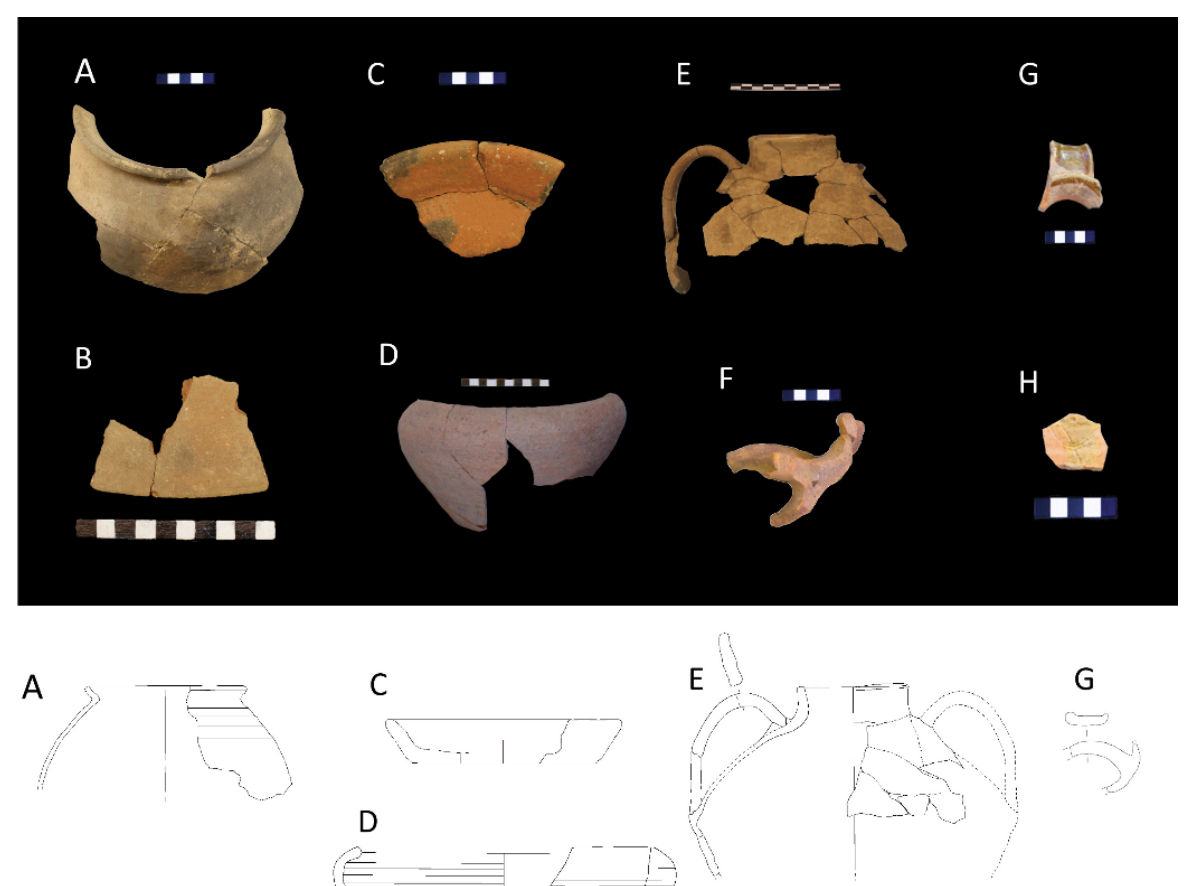

G
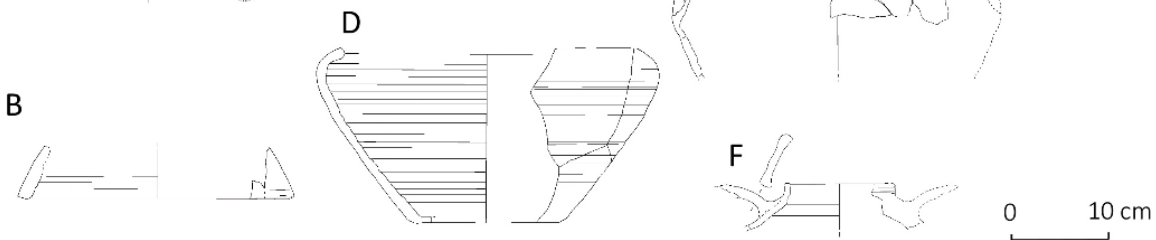

Figure 3. Some fragments from the investigated ceramic assemblage: (A-C) cooking ware; (D) table and storage ware; $(\mathbf{E}, \mathbf{F})$ small transport amphorae; $(\mathbf{G}, \mathbf{H})$ sparse-glazed ware.

\subsection{Experimental}

The geochemical investigation of the repertory was carried out via a combined pXRF and is supported by references to traditional mineralogical and petrographic studies.

The mineralogical and structural investigation was performed on thin sections using a LEICA DMRX optical polarizing microscope to provide a detailed characterization of both the matrix (homogeneity, color, iso-orientation and porosity) and the inclusions (composition, grain size, frequency, roundness, sorting) that are either naturally present or artificially added. The textural elements were estimated using suitable comparative charts $[51,75,76]$.

The chemical characterization was performed using portable X-ray fluorescence (pXRF) with an Olympus INNOV-X Delta Premium DP-6000-C that was equipped with a $40 \mathrm{kV}, 4 \mathrm{~W}$ and 200 microampere X-ray tube, Rh anode and a large-area SSD detector. All of the pottery samples were cleaned with water and an ordinary nylon-bristle toothbrush to remove the soil and particulate matter that was loosely adhered to the surface. Coatings were also removed when present. A representative portion of each fragment (proportional to the average crystal size) was then powdered to ensure the proper homogenization of the sample [77].

The analysis was performed in soil mode, which has proved in the past to be suitable for ceramic studies [78,79]. Even though major elements, such as $\mathrm{Mg}$, $\mathrm{Si}$ or $\mathrm{Al}$, cannot be determined, 'soil' mode analysis yields a large suite of minor and trace elements. The selected lifetime of the measurements, which were carried out in air, was $30 \mathrm{~s}$ for each sample, measuring in three energy ranges (two at $40 \mathrm{KeV}$ and one at $15 \mathrm{KeV}$ ) for the analysis of the elements with the lowest atomic weight. During each measurement, a photograph of the analyzed area was recorded with the integrated camera. All of the samples were analyzed at three different spots in order to account for any uncertainties that were potentially introduced by the method or by the selection of the measurement area. In previous studies, up to five measurements have been suggested for the pXRF analysis of 
coarse ceramics in order to collect results with adequate precision [24]. A set of 33 elements were measured, but those with concentration values below or near the LOD were cleared from the list. Fourteen elements were at last used for an initial statistical evaluation: As, $\mathrm{Ca}, \mathrm{Cr}, \mathrm{Cu}, \mathrm{Fe}, \mathrm{K}, \mathrm{Mn}, \mathrm{Ni}, \mathrm{Pb}, \mathrm{Rb}, \mathrm{Sr}, \mathrm{Ti}, \mathrm{Zn}$ and $\mathrm{Zr}$.

The soil method is a Compton normalization approach that is calibrated for the analysis of elements whose chemical concentration is less than $2 \%$, although good results can also be obtained for higher concentrations [80]. To ensure the highest reproducibility of the measurements, the instrument was used in benchtop mode and the samples were placed in special Teflon sample holders and sealed with a Mylar film.

\subsection{Data Processing}

In order to determine the most suitable set of elements for investigating the variance of the whole repertory of ceramic fragments, the relative standard deviations (RSD) were calculated (Table 1).

Table 1. The RSDs that are representative of each element, calculated from all assays taken from the powdered samples. RSD values of the whole repertory, as well as from the assemblages from the reference sites of Castellina, Donoratico, Monterotondo Marittimo and Roccastrada, are reported.

\begin{tabular}{|c|c|c|c|c|c|c|c|c|c|c|c|c|c|c|}
\hline \multicolumn{15}{|c|}{ TOTAL } \\
\hline Element & $\mathrm{K}$ & $\mathrm{Ca}$ & $\mathrm{Ti}$ & $\mathrm{Cr}$ & Mn & $\mathrm{Fe}$ & $\mathrm{Ni}$ & $\mathrm{Cu}$ & $\mathrm{Zn}$ & As & $\mathrm{Zr}$ & $\mathbf{P b}$ & $\mathbf{R b}$ & $\mathrm{Sr}$ \\
\hline Mean (ppm) & 26,868 & 26,662 & 4197 & 221 & 639 & 34,949 & 75 & 29 & 76 & 40 & 209 & 1781 & 186 & 163 \\
\hline Population STD & 4240 & 28,373 & 815 & 141 & 356 & 10,049 & 42 & 13 & 20 & 67 & 59 & 4790 & 58 & 104 \\
\hline RSD \% & 16 & 93 & 19 & 64 & 56 & 29 & 56 & 46 & 26 & 167 & 28 & 269 & 31 & 64 \\
\hline \multicolumn{15}{|c|}{ Castellina } \\
\hline Element & K & $\mathrm{Ca}$ & $\mathrm{Ti}$ & $\mathrm{Cr}$ & Mn & $\mathrm{Fe}$ & $\mathrm{Ni}$ & $\mathrm{Cu}$ & $\mathrm{Zn}$ & As & $\mathrm{Zr}$ & $\mathrm{Pb}$ & $\mathbf{R b}$ & $\mathrm{Sr}$ \\
\hline Mean (ppm) & 28,360 & 29,768 & 4139 & 171 & 567 & 31,807 & 60 & 25 & 72 & 34 & 228 & 482 & 214 & 192 \\
\hline Population STD & 4284 & 28,531 & 743 & 101 & 311 & 9820 & 31 & 10 & 19 & 30 & 63 & 2107 & 52 & 96 \\
\hline RSD \% & 15 & 89 & 18 & 59 & 55 & 31 & 52 & 40 & 26 & 87 & 27 & 437 & 24 & 50 \\
\hline \multicolumn{15}{|c|}{ Donoratico } \\
\hline Element & K & $\mathrm{Ca}$ & $\mathrm{Ti}$ & $\mathrm{Cr}$ & Mn & $\mathrm{Fe}$ & $\mathrm{Ni}$ & $\mathrm{Cu}$ & $\mathrm{Zn}$ & As & $\mathrm{Zr}$ & $\mathbf{P b}$ & $\mathbf{R b}$ & $\mathrm{Sr}$ \\
\hline Mean (ppm) & 24,651 & 5588 & 4982 & 440 & 695 & 43,026 & 139 & 30 & 78 & 51 & 210 & 3916 & 128 & 69 \\
\hline Population STD & 2089 & 1380 & 320 & 107 & 414 & 7874 & 23 & 10 & 15 & 110 & 33 & 5522 & 10 & 10 \\
\hline RSD \% & 8 & 25 & 6 & 24 & 59 & 18 & 16 & 34 & 20 & 216 & 15 & 141 & 8 & 14 \\
\hline \multicolumn{15}{|c|}{ Monterotondo Marittimo } \\
\hline Element & K & $\mathrm{Ca}$ & $\mathrm{Ti}$ & $\mathrm{Cr}$ & Mn & $\mathrm{Fe}$ & $\mathrm{Ni}$ & $\mathrm{Cu}$ & $\mathrm{Zn}$ & As & $\mathrm{Zr}$ & $\mathbf{P b}$ & $\mathbf{R b}$ & $\mathrm{Sr}$ \\
\hline Mean (ppm) & 27,318 & 39,202 & 4339 & 178 & 924 & 39,742 & 70 & 35 & 90 & 30 & 147 & 24 & 146 & 171 \\
\hline Population STD & 4529 & 20,773 & 687 & 23 & 336 & 5501 & 28 & 11 & 13 & 23 & 29 & 6 & 50 & 97 \\
\hline RSD \% & 17 & 53 & 16 & 13 & 36 & 14 & 40 & 30 & 15 & 75 & 20 & 24 & 34 & 57 \\
\hline \multicolumn{15}{|c|}{ Roccastrada } \\
\hline Element & K & $\mathrm{Ca}$ & $\mathrm{Ti}$ & $\mathrm{Cr}$ & Mn & $\mathrm{Fe}$ & $\mathrm{Ni}$ & $\mathrm{Cu}$ & $\mathrm{Zn}$ & As & $\mathrm{Zr}$ & $\mathbf{P b}$ & $\mathbf{R b}$ & $\mathrm{Sr}$ \\
\hline Mean (ppm) & 22,435 & 8285 & 3120 & 152 & 510 & 29,533 & 41 & 26 & 67 & 35 & 159 & 39 & 201 & 82 \\
\hline Population STD & 2728 & 2643 & 538 & 47 & 339 & 7915 & 13 & 8 & 17 & 44 & 43 & 10 & 47 & 38 \\
\hline RSD \% & 12 & 32 & 17 & 31 & 66 & 27 & 32 & 31 & 25 & 127 & 27 & 27 & 24 & 47 \\
\hline
\end{tabular}

If the whole repertory of samples is considered, most of the elements showed an RSD\% ranging between 16 and $93 \%$, with the exception of $\mathrm{As}$ and $\mathrm{Pb}$, which were characterized by higher values (167\% and $269 \%$, respectively). From a more in-depth investigation of the single repertories from the reference sites, the reasons for the high RSD values for As and $\mathrm{Pb}$ were found to have resulted from their being mainly correlated to the sparse-glazed ware samples from Donoratico, suggesting that an external factor was responsible for the observed $\mathrm{Pb}$ fluctuations. The sparse-glazed wares consisted of single-fired lead-glazed ceramics, where a suspension of $\mathrm{PbO}$ (alone or mixed with $\mathrm{SiO}_{2}$ ) was applied to leatherhard bodies to obtain a transparent coating [81]. Depending on the firing conditions, a more or less extended diffusion of lead within the ceramic body could occur and the detection of 
high levels of lead in some of the glazed samples was considered to be a consequence of the incomplete removal of the external layers during sampling procedures.

The exploitation of a number of different lead deposits during the late Roman and early medieval periods has been widely documented [59,82-84]. Arsenic (together with other elements, such as silver, iron, or zinc) is frequently associated with poly-metallic sulfide deposits and could be present as an impurity in the final product [85].

The investigation of $\mathrm{Pb}$ and As levels in glazed ware samples showed a peculiar correlation between those fragments where the use of lead from southern Tuscany was assumed [10] and the presence of high levels of arsenic was again related to the diffusion of the glazing mixture within the ceramic body (Figure 4). The Roccastrada assemblage was also characterized by a high RSD\% value for As. The reasons for the As anomaly were in this case related to the geology of the area and, in particular, to the intense hydrothermal activity that affected the primary rhyolitic rocks and which caused an enrichment in As $[70,86]$.

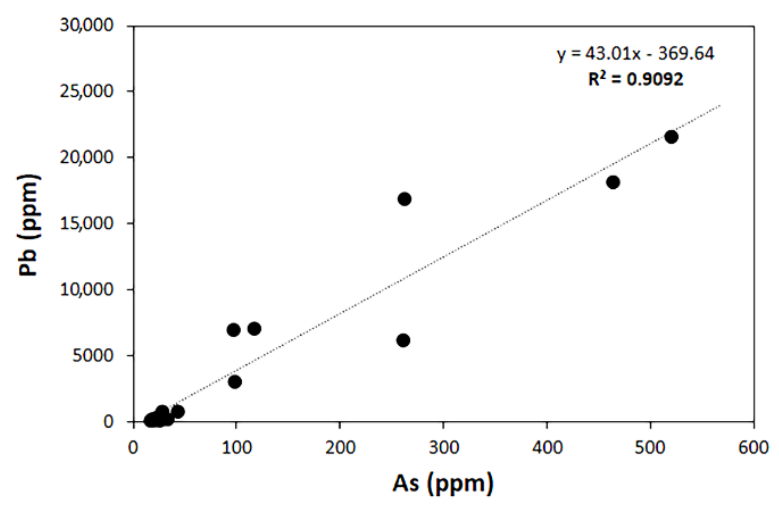

Figure 4. $\mathrm{Pb} / \mathrm{As}$ bi-plot of glazed ware. Trend line and $\mathrm{r}^{2}$ are reported.

Despite the fact that As could represent a marker that would help us discriminate between the use of raw materials from Roccastrada and other contexts, the anomaly that was registered for Donoratico suggested that lead and arsenic should be excluded from the analysis. Together with $\mathrm{Pb}$ and As, those elements that are known to be affected by other external factors (Cl, P, Ba and S) have also been excluded [21]. Due to the diffused presence of mixed sulfide formations in southern Tuscany, the inclusion of $\mathrm{Cu}$ and $\mathrm{Zn}$ in the dataset was considered to be significant for a more detailed grouping of the samples.

The chemical dataset was then pre-treated in order to minimize the influence of matrix effects and reduce distinctions in the magnitudes between major and trace elements [87]. Previous studies have discussed the identification of a more suitable type of transformation for investigating a closed archaeological dataset [42,44,47,48,88-90]. Among other techniques, the normalization of the data according to titanium and the standard $\log 10$ transformations have been compared in the present study.

Normalization according to a major element (or signals from the cathode) allowed us to limit experimental errors and fluctuations (e.g., irregular surfaces, small variations of the sample-instrument distance) and helped us ensure a higher level of analytical reproducibility [91,92]. Spearman's correlation was used to investigate the relationships between major, minor and trace elements, and titanium was then identified as the most representative element for the present chemical dataset [47,93].

On the other hand, $\log 10$ transformation was considered, as it compensates well for the differences in magnitudes between the major elements and the trace elements $[42,87]$.

\section{Results}

The petrographic investigation of reference samples allowed us to identify the main mineralogical features that correspond to different areas of production (Table 1). 
The fragments from Donoratico (fabric group DON, Figure 5a) were characterized by quartzose-feldspathic inclusions, which were the main mineralogical phases, with minor quantities of micas, opaque minerals, secondary calcite and rare pyroxenes. Lithic fragments were also observed, which mainly consisted of meta-arenites and siltites, together with rare intrusive rocks. Previous studies on the mineralogical and chemical features of these samples [10] also showed the diffuse presence of Fe and Ti oxides, together with lower amounts of spinel (mainly from the chromite series), titanite, monazite, and apatite.

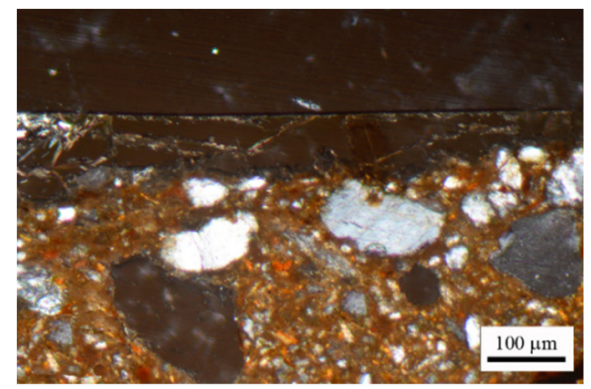

(a)

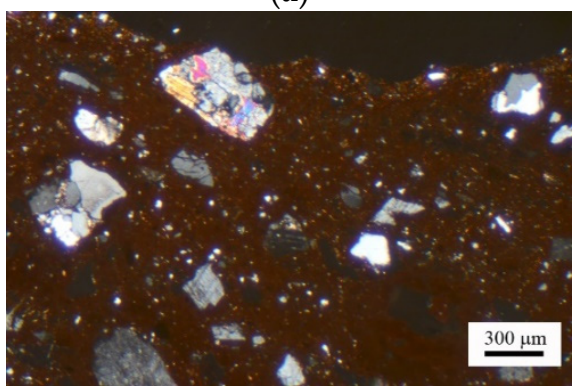

(c)

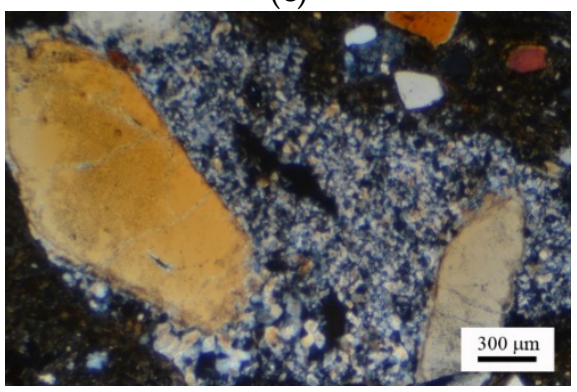

(e)

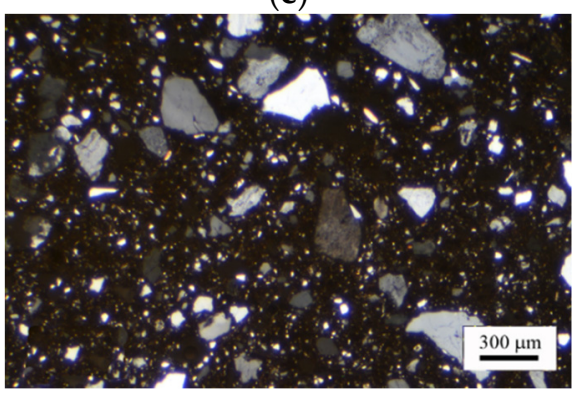

(g)

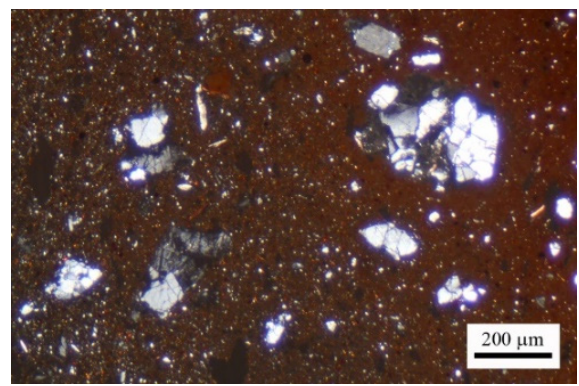

(b)

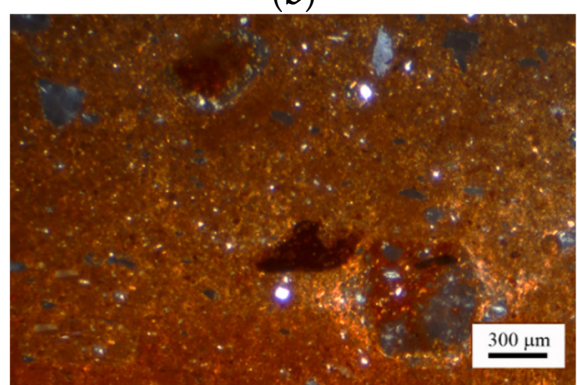

(d)

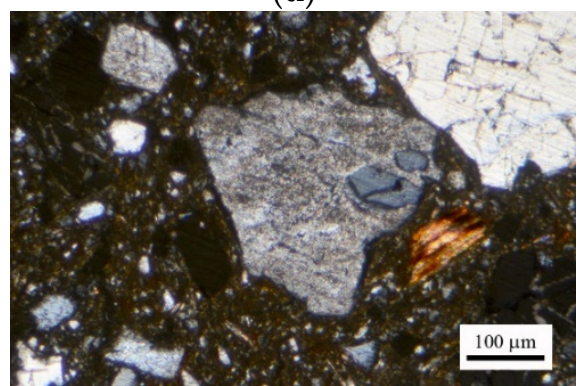

(f)

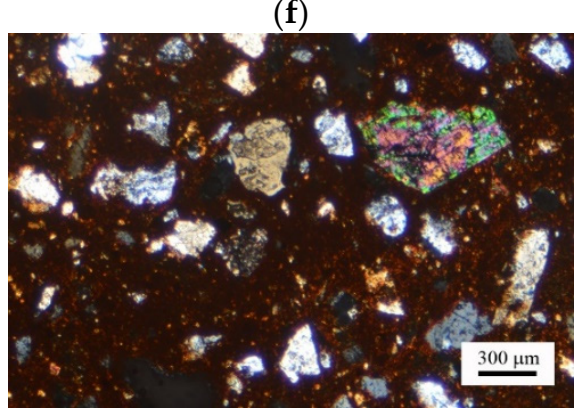

(h)

Figure 5. Microphotograph of selected samples from the fabric groups identified following the petrographic investigation: (a) sample DON194a, fabric group DON; (b,c) samples RA22 (fabric group MR1) and MR21 (fabric group MR2) from Monterotondo Marittimo; (d) sample RS35, fabric group RS1; (e) sample RS87, fabric group RS2; (f) sample RS24, fabric group RS3; (g) sample CSN124, fabric group RS4; (h) sample CSN221, fabric group EXT. 
The ceramic assemblage from Monterotondo Marittimo was characterized by its having calcareous pastes where the predominant mineralogical inclusions were represented by quartz, together with feldspars (both plagioclase, K-feldspar), biotite, secondary calcite granules, sub-rounded rock fragments quartz arenite, siltstones and siliceous limestones. Minor amounts of clay pellets, opaque minerals and relics of microfossils (mainly ostracods) were also observed (fabric group MR1, Figure 5b), while rare mafic intrusive rock inclusions were detected in some of the samples (fabric group MR2, Figure 5c).

The fabrics from Roccastrada were characterized by the use of high-silica mineral inclusions, which were mainly represented by mono-crystalline quartz grains with sub-angular shape and a high degree of particle size standardization, suggesting a deliberate addition of a siliceous sand to the clay (fabric groups RS1, RS2, RS3 and RS4, Figure 5d-g, respectively). Subordinate amounts of rock fragments (poly-crystalline quartz and quartzite) and inclusions of volcanic origin (sub-rounded fragments of rhyolite and/or glass) were also observed, together with feldspars (mainly plagioclase), biotite, clay pellets, rare pyroxenes and opaque minerals.

Petrographic observations of the Vetricella assemblage allowed us to assign most of the samples to the above-described fabric groups. Only a few glazed ware samples showed peculiar features, suggesting the different provenance of the raw materials (likely extra-regional). A further fabric group was then identified (fabric group EXT, Figure 5h). All of the samples belonging to EXT group were characterized by large amounts of calcareous/dolomitic pastes where the predominant mineralogical phases were represented by quartz (mono and polycrystalline) and feldspars, together with frequent carbonates and micas. The carbonates mainly consisted of variable amounts of spathic and/or micritic calcite, together with rare bioclastic and/or dolomitic inclusions. Subordinate quantities of opaque minerals, rock fragments (flint and rare sandstone with clayey matrix) and rare pyroxenes and garnet inclusions were also observed.

Principal component analysis of the Ti-normalized and Log10 datasets was first of all performed on reference samples. Four components were extracted that represented 79.23\% and $80.39 \%$ of the total variance of Ti-normalized and Log10 data, respectively. Biplots of the two first components of each PCA are shown in Figure 6a,b.

For the Ti-normalized dataset, PC1 (principal component 1) represented $38.90 \%$ of the total variance and allowed us to distinguish between high-Ca and low-Ca pastes, as well as between more weathered items (such as Rb-rich kaolinized intrusives, or shales). On the other hand, PC2 represented $15.24 \%$ of the total variance and was influenced by the presence of $\mathrm{Cr}$ - and Ni-bearing mineral phases.

The $\log 10$ statistical dataset, where PC1 and PC2 described $37.47 \%$ and $24.42 \%$ of the total variance, respectively, provided a better grouping of the samples. Contrary to Ti-normalized dataset, PC1 and PC2 are herein described by the nature of the mineral inclusions and the nature of the clay, respectively. From both the Ti-normalized and log 10 PCAs it was possible to easily distinguish between the pastes from Donoratico from those of the internal areas (Monterotondo Marittimo and Roccastrada), where the main discriminant in represented by the use of a different temper in association with more or less calcareous clays. Due to the calcareous/dolomitic nature of the clays that were used for glazed ware pastes, the samples belonging to the EXT group represented the more calcareous terms of the series, but they could not be discriminated from local high-Ca pastes.

Once the main features of the reference samples were defined, the statistical analysis was then extended to the whole repertory to investigate the chemical variance of the samples from Vetricella. Four components were extracted that represented $79.91 \%$ and $80.19 \%$ of the total variance of Ti-normalized and Log10 data, respectively. Biplots of the two first components of each PCA are shown in Figure 6c,d. PC1 and PC2 represented, respectively, $32.35-29.91 \%$ and $36.02-20.74 \%$ of the total variance for Ti-normalized and $\log 10$ PCAs, respectively.

The PCA analysis of the whole repertory showed the highly heterogenous nature of the ceramic assemblage from Vetricella, with data superimposed on the groups that were 
identified by the reference samples. The petrographic analysis of the samples also provided a better assessment of the variations due to temper-related issues.

The combined use of PCA and petrographic analysis indicated a large incidence of Roccastrada pastes among the Vetricella fabrics (67\%), while Monterotondo Marittimo $(19 \%)$, Donoratico $(10 \%)$ and extra-regional $(4 \%)$ pastes were less represented.

The incidence of the different ceramic functional classes or shapes within the Vetricella assemblage is reported in Figure 7a. If the results from the petrographic and chemical analysis are considered, the samples belonging to the Roccastrada ateliers consisted of small amphorae $(55 \%)$, likely used for the transportation of goods (so-called small transport amphorae, or STA), cooking ware (23\%) and table and storage ware $(21 \%)$. On the contrary, the samples with a geochemical and mineralogical association with the Monterotondo Marittimo area showed a higher incidence of table and storage ware (50\%), together with minor amounts of STAs (38\%) and cooking ware $(13 \%)$. Finally, glazed ware represented the only ceramic class representative of the Donoratico region and extra-regional production (Figure $7 b$ ).

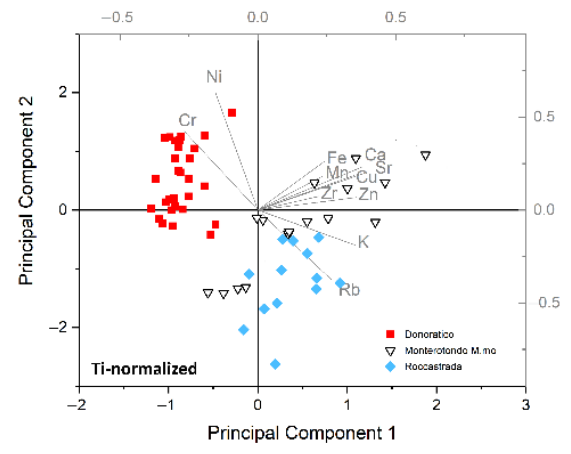

(a)

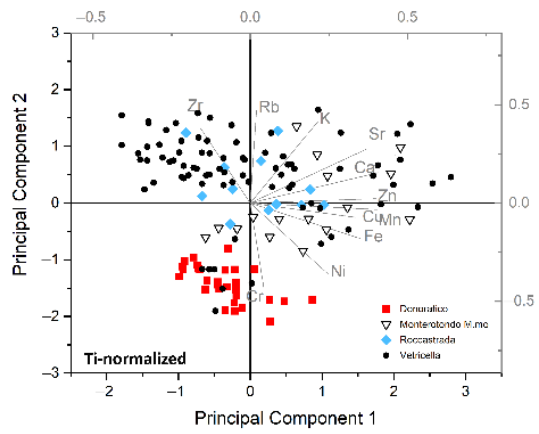

(c)

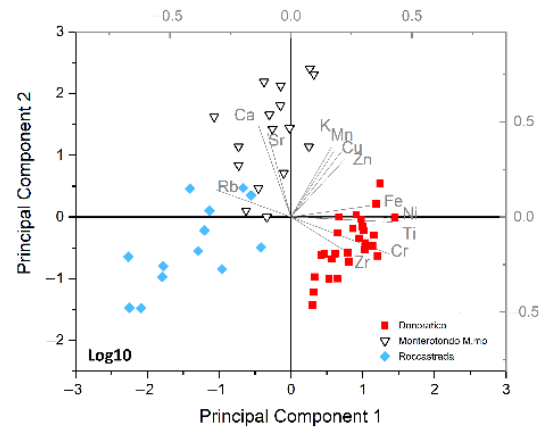

(b)

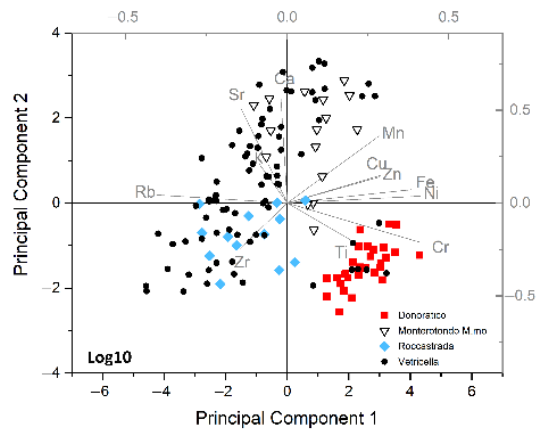

(d)

Figure 6. Bivariate plots from the PCA analysis of the Ti-normalized and log10 datasets relative to: $(\mathbf{a}, \mathbf{b})$ the reference ceramic samples; and $(\mathbf{c}, \mathbf{d})$ the whole repertory. 


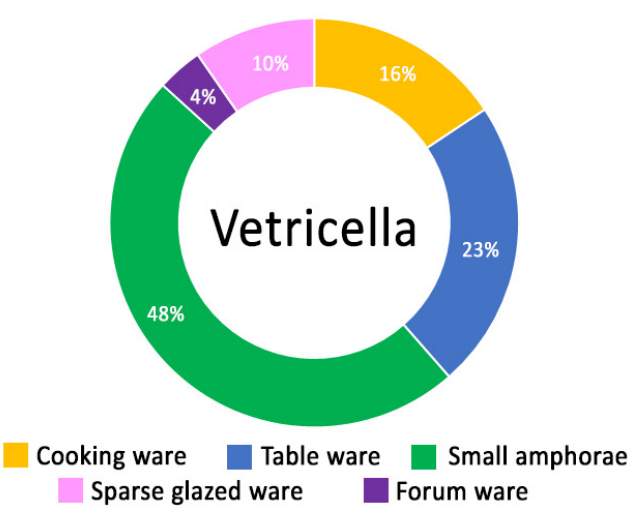

(a)

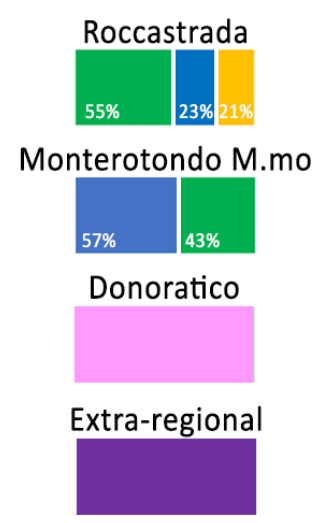

(b)

Figure 7. Outline of the main features of the Vetricella assemblage investigated in the present study according to the results from the archaeological, geochemical and petrographic analyses: (a) pie chart showing the main ceramic functional classes; (b) tree charts showing where the Vetricella assemblage is associated with different production areas depending on the mineralogical and geochemical nature of the pastes. The incidence of each ceramic functional class is also reported.

\section{Discussion}

The results of the investigation of the reference samples indicated how assemblages and materials can be distinguished from each other through the combined use of petrographic and non-destructive pXRF analysis. Based on the elements used in this analysis, the geochemical signatures of the samples showed more or less pronounced differences between the ceramic assemblages originating from different sites, while the petrographic investigation of the ceramic pastes provided a more detailed contextualization of the geochemical data.

Both mineralogical and geochemical data were strongly in agreement with the complex geology of southern Tuscany.

The reference samples from Roccastrada mainly consisted of cooking ware where the intentional addition of a temper, represented by abundant quartz with subordinate and variable amounts of clay pellets, rhyolite and volcanic glass, was observed. In the PCA bi-plots, the samples from Roccastrada formed a more dispersed group that was characterized by a good correlation with $\mathrm{Rb}$, where the abundance and the mineralogical composition of the temper played a significant role in the definition of slight discrepancies in the geochemical signature.

The geology of the Roccastrada area is characterized by a diffused presence of Miocenic marine clays, represented by fine-grained blue clays with quite abundant micro-fauna (Argille Azzurre Formation) and gray clays with intercalated fine-grained sandstones (Torrente Raquese Formation, or Pycnodonta clays). The abundance of refractory materials, such as volcanic rocks (rhyolite and volcanic glass) and highly siliceous rock assemblages, promoted an intense production of refractory ceramic, such as cooking ware and technical ceramic for smelting activities.

The rhyolites of Roccastrada mainly consist of glass (53\%), quartz (14-15\%), K-feldspar $16 \%$, plagioclase $(8-9 \%)$, biotite (3-6\%) and cordierite (2\%), with minor apatite and zircon [70]. $\mathrm{Rb}^{+}$substitutes frequently for $\mathrm{K}^{+}$in K-feldspars, micas and clay minerals, with a natural tendency to concentrate during the weathering of the parent rock due to ion exchange and adsorption mechanisms. In magmatic systems, $\mathrm{Rb}^{+}$highly concentrates during late stages and could substitute for $\mathrm{K}^{+}$in $\mathrm{K}$-bearing phyllosilicates (such as mica and biotite) and, to a lesser extent, in K-feldspar [86]. During the first weathering stages, the dismantling of biotite and the plagioclase present in rhyolitic rocks leads to a depletion in $\mathrm{Rb}$. In the last stages, following the decomposition of $\mathrm{K}$-feldspars and the alteration of zircon, a consequent increase in $\mathrm{Rb}$ depletion, together with $\mathrm{K}$ and $\mathrm{Zr}$, is documented [70]. 
As observed for the samples of Roccastrada, the heterogeneous textural and mineralogical features observed for the fragments from Monterotondo Marittimo represented the main reason for higher fluctuations in the chemical composition. Most of the fineand medium-grained vessels from this group were mainly represented by a good correlation with $\mathrm{Ca}$ (together with $\mathrm{Sr}$ ) and $\mathrm{K}$, while some coarse ware fragments constituted an intermediate cluster that was represented by $\mathrm{Rb}$.

The correlation of fine- and medium-grained samples with Ca was in accord with the geology of Monterotondo Marittimo, as it is mainly represented by the diffuse presence of Miocenic blue marine clays, together with limestones, marl and polygenic marine conglomerates. Quartzose-feldspathic-micaceous sandstone (Macigno Formation) are also abundant, while sporadic gabbroic intrusions have been observed within the more extended outcrops related to Palombino shales. The use of a quartzose-feldspathic temper and/or a less purified clay, or at least a different clay source, was assumed to be responsible of the peculiar association of the coarser fabrics with $\mathrm{Rb}$.

As for the fine-grained ware from Monterotondo, the glazed ware fragments belonging to the EXT group were well represented by Ca. The chemical and mineralogical composition of this group accords well with the geology of the Roman and northern Latium areas, characterized by the presence of Pliocenic marls and basic volcanites [94,95].

Finally, the sparse-glazed ware from Donoratico represented a well-defined group characterized by a peculiar correlation with $\mathrm{Cr}, \mathrm{Ni}$ and Ti. Highly serpentinized ophiolite fragments, in addition to the presence of chromite and abundant quartz, together with minor amounts of $\mathrm{Cr}$-spinel and $\mathrm{Cr} / \mathrm{Ni}$-rich pyroxene, have been documented in the sedimentary materials from Val di Cecina [96]. The identification of Cr- and Ni-bearing minerals was closely associated with the fractioning processes that are produced by the weathering and dismantling of the ophiolitic outcrops present in the area.

Previous studies on sparse-glazed ware manufacture in Donoratico confirmed the existence of dedicated ateliers in the area and the exploitation of local raw materials [59].

The introduction of the fragments from Vetricella in the statistical database revealed a wide distribution within the compositional clusters that was defined by the reference samples and which suggested the existence of a wide circulation of pottery converging towards the southern Tuscany coast.

The results from the PCA were in agreement with the petrographic analysis of the fabrics and paved the way for important considerations about the circulation and consumption of ceramics in the area during the Early Middle Ages that could be supported by further archaeological and archaeometric investigation on a large scale.

The first indications arising from the results of the present study stressed the central role of Vetricella as a collector of goods from different areas of southern Tuscany and provided impetus for future investigations that might help formulate a more detailed definition of the trading routes to and from Vetricella (Figure 8).

The comparison of the results of the geochemical and petrographic examinations of the studied repertory suggested a well-defined exploitation of raw materials across the Colline Metallifere in relation to the manufacture of artefacts with different intended uses. From the analysis of the whole repertory, it was possible to observe how coarse-grained pastes mainly showed a higher incidence of geochemical and mineralogical markers for Roccastrada, while fine- and medium-grained fabrics were equally distributed among the Monterotondo and Roccastrada fabric groups, as well as within the geochemical clusters. The sparse-glazed ware from Vetricella finally showed strong analogies with the Donoratico assemblage. 


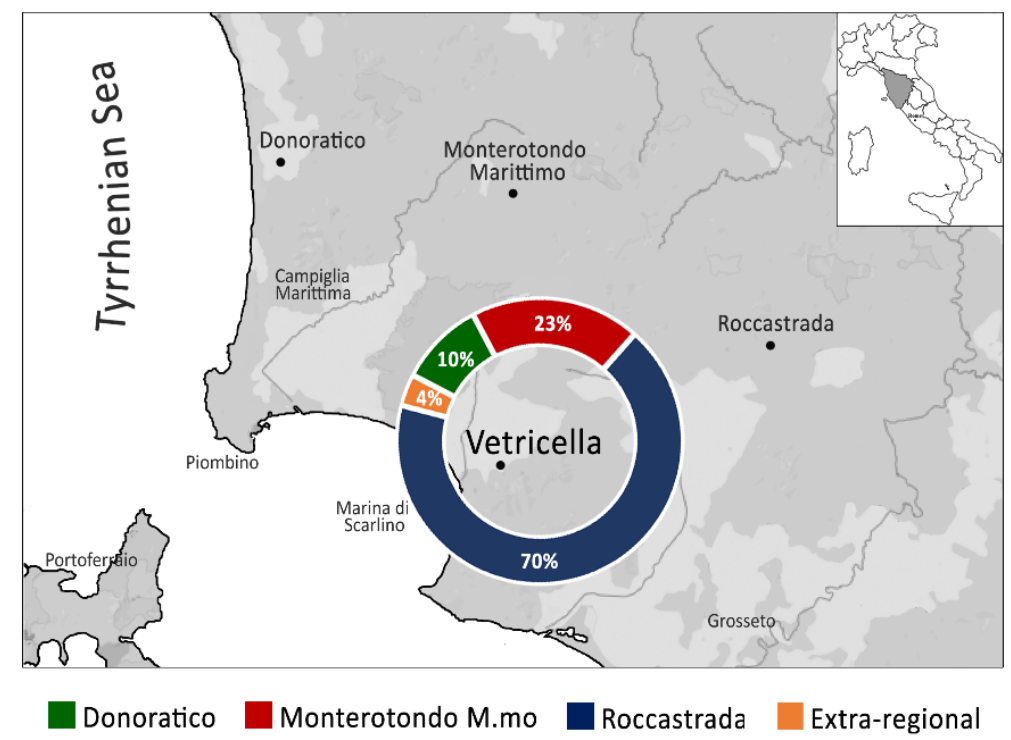

Figure 8. Outline of the results from the geochemical investigation of the ceramic assemblage from Vetricella, overlaying the geographical maps of the area. The pie chart represents the Vetricella assemblage according to the provenance of the pastes from different areas.

Small amphorae (STA) represent an interesting case study. This peculiar, doublehandled closed shape was first identified during previous archaeological investigations in different sites in southern Tuscany [7]. As it stands at present, it is not possible to provide an exhaustive contextualization of the use and circulation of STAs in the region. Nevertheless, the exceptional number of STA fragments returned from the last excavations in Vetricella provides new clues to support further research within this framework.

In the present study, STAs represented $48 \%, 55 \%$ and $38 \%$ of the whole ceramic assemblage from Vetricella, Roccastrada and Monterotondo Marittimo, respectively. STA fragments from Vetricella, in particular, had a highly heterogenous composition where the chemical and mineralogical markers of both Monterotondo Marittimo (23\%) and Roccastrada (77\%) were observed. Previous studies also showed the presence in Vetricella of a few fragments related to some ateliers located in the coastal area [61].

The relevant amount of STAs produced with local raw materials suggested the extensive manufacture of handled closed shapes, likely intended for circulation as a local alternative to the import of amphorae from the south of the peninsula, though this traffic is still scarcely documented along the coastal and sub-coastal strip of Tuscany [97], and evidence regarding the nature of the transported materials are still poor.

Further investigations will be thus vital to provide an accurate characterization of STA manufacture and consumption, as well as a detailed definition of the exchange routes within the territory.

\section{Conclusions}

The present work aimed to contribute to the long-lasting debate surrounding the successful use of pXRF with archaeological materials. While the widespread application of portable analytical methods to archaeological issues prompted a number of multidisciplinary studies, the non-negligible limits in the investigation of highly heterogenous materials restricted the use of $\mathrm{pXRF}$ to pottery assemblages.

Based upon the indications arising from the comparison with the more solid petrographic analysis and the application of statistical methods, pXRF was here used as a powerful tool for a broad 'screening' of a large repertory of fragments and provided a reliable internal grouping of a 'closed' population of samples.

In the future, the limitations arising from the detection of chemical elements within a restricted dataset could be reduced via the application of more sensitive analytical methods 
on selected samples. The detection of a wider array of chemical elements (comprehensive of light elements and REE) will help to more accurately distinguish between the sub-groups, and lead to the creation of a well-defined database to support further pXRF examinations of additional unstudied fragments.

The combined use of $\mathrm{pXRF}$ and statistical analysis facilitated the geochemical grouping of the ceramic assemblage, providing clues about the convergence of different commercial routes towards the site of Vetricella that reveal its key role as a central site dedicated to the collection and re-distribution of a wide and heterogeneous range of goods that were produced in the area, as also indicated by the presence of glazed pottery that required highly skilled labour.

The petrographic investigation also supported a more in-depth analysis of the fabrics, particularly concerning those samples where the chemical clustering was uncertain.

Despite the fact that the repertory that we studied here represents just a limited selection of samples from all of the sites cited in the present work, the results allowed us to show how ceramic manufacture was diffused via trading capillaries across a wide area, i.e., the Colline Metallifere. In contrast with previous studies, the study also suggested that the diffused ateliers were tightly interconnected, while the archaeological data indicated how the ceramic production was strongly dependent on the complex management of local resources that were under the control of the royal authority.

In the debate about pXRF application in the archaeological sciences, the recent huge increase in the use pXRF instruments by conservators and archaeologists represents another controversial point [19]. Beside the purely analytical and technical issues, the present work also wanted to stress the importance of tight cooperation between scientists and archaeologists, which would help us to develop a more solid analytical strategy and provide reliable answers to archaeological and historical questions.

The interdisciplinary interpretation of the analytical data here also paves the way for the organization of future investigations that are focused on different and more specific topics where the application of more solid analytical methods could help to delineate a more accurate picture of pottery circulation to and from Vetricella on a larger scale.

Supplementary Materials: The following are available online at https: / www.mdpi.com/article / 10.3390 /app112411859/s1, Table S1: Summary of the main petrographic features of the ceramic assemblage from Vetricella. Samples have been grouped after the identification of the area of provenance of the raw materials according to the mineralogical composition of the ceramic bodies. Table S2: Summary of the main petrographic features of the reference ceramic assemblages from Monterotondo Marittimo, Roccastrada and Donoratico. Samples have been grouped after the identification of the area of provenance of the raw materials according to the mineralogical composition of the ceramic bodies.

Author Contributions: Conceptualization, C.F., V.V., E.P., L.R. and G.B.; Data curation, C.F.; Formal analysis, C.F. and V.V.; Funding acquisition, G.B.; Investigation, C.F.; Methodology, C.F. and V.V.; Project administration, G.B.; Supervision, M.G., A.D. and G.B.; Writing-Original draft, C.F. and V.V.; Writing-Review and editing, E.P., L.R. and A.B. All authors have read and agreed to the published version of the manuscript.

Funding: This research carried out in the framework of the nEU-Med project, Origins of a new economic union (7th-12th centuries): resources, landscapes and political strategies in a Mediterranean region. The project received fundings from the European Research Council (ERC) under the European Union's Horizon 2020 research and innovation program (grant agreement n. 670792).

Institutional Review Board Statement: Not applicable.

Informed Consent Statement: Not applicable.

Data Availability Statement: The data presented in this study are available on request from the corresponding author. 
Acknowledgments: We are grateful to the entire nEU-Med research team for their kind assistance for all the scientific and logistic support during the fieldwork. Finally, our thanks go to the three anonymous referees for all their helpful suggestions and comments on the first draft of this paper.

Conflicts of Interest: The authors declare no conflict of interest.

\section{References}

1. Hein, A.; Kilikoglou, V. Compositional variability of archaeological ceramics in the eastern Mediterranean and implications for the design of provenance studies. J. Archaeol. Sci. Rep. 2017, 16, 564-572. [CrossRef]

2. Hayes, K. Parameters in the use of pXRF for archaeological site prospection: A case study at the Reaume Fort Site, Central Minnesota. J. Archaeol. Sci. 2013, 40, 3193-3211. [CrossRef]

3. Liritzis, I.; Xanthopoulou, V.; Palamara, E.; Papageorgiou, I.; Iliopoulos, I.; Zacharias, N.; Vafiadou, A.; Karydas, A.G. Characterization and provenance of ceramic artifacts and local clays from Late Mycenaean Kastrouli (Greece) by means of p-XRF screening and statistical analysis. J. Cult. Herit. 2020, 46, 61-81. [CrossRef]

4. Emmitt, J.J.; McAlister, A.J.; Phillipps, R.S.; Holdaway, S.J. Sourcing without sources: Measuring ceramic variability with pXRF. J. Archaeol. Sci. Rep. 2018, 17, 422-432. [CrossRef]

5. Cannavò, V.; Photos-Jones, E.; Levi, S.T.; Brunelli, D.; Fragnoli, P.; Lomarco, G.; Lugli, F.; Martinelli, M.C.; Sforna, M.C. p-XRF analysis of multi-period Impasto and Cooking Pot wares from the excavations at Stromboli-San Vincenzo, Aeolian Islands, Italy. STAR Sci. Technol. Archaeol. Res. 2017, 3, 326-333. [CrossRef]

6. LeMoine, J.B.; Halperin, C.T. Comparing INAA and pXRF analytical methods for ceramics: A case study with Classic Maya wares. J. Archaeol. Sci. Rep. 2021, 36, 102819. [CrossRef]

7. Bianchi, G.; Hodges, R. Origins of a New Economic Union (7th-12th Centuries): Preliminary Results of the nEU-Med Project: October 2015-March 2017; All'insegna del Giglio: Sesto Fiorentino, Italy, 2018.

8. Bianchi, G.; Hodges, R. The nEU-Med Project: Vetricella, an Early Medieval Royal Property on Tuscany's Mediterranean; All'insegna del Giglio: Sesto Fiorentino, Italy, 2020; ISBN 9788878149717.

9. Michałowski, A.; Niedzielski, P.; Kozak, L.; Teska, M.; Jakubowski, K.; Źółkiewski, M. Archaeometrical studies of prehistoric pottery using portable ED-XRF. Meas. J. Int. Meas. Confed. 2020, 159, 107758. [CrossRef]

10. Glascock, M.D.; Neff, H.; Stryker, K.S.; Johnson, T.N. Sourcing archaeological obsidian by an abbreviated NAA procedure. J. Radioanal. Nucl. Chem. 1994, 180, 29-35. [CrossRef]

11. Gratuze, B. Obsidian characterization by laser ablation ICP-MS and its application to prehistoric trade in the Mediterranean and the Near East: Sources and distribution of obsidian within the Aegean and Anatolia. J. Archaeol. Sci. 1999, 26, 869-881. [CrossRef]

12. Cochrane, E.E.; Neff, H. Investigating compositional diversity among Fijian ceramics with laser ablation-inductively coupled plasma-mass spectrometry (LA-ICP-MS): Implications for interaction studies on geologically similar islands. J. Archaeol. Sci. 2006, 33, 378-390. [CrossRef]

13. Palanivel, R.; Meyvel, S. Microstructural and microanalytical study-(SEM) of archaeological pottery artefacts. Rom. J. Phys. 2010, 55, 333-341.

14. Shackley, M.S. Gamma Rays, X-rays and Stone Tools: Some Recent Advances in Archaeological Geochemistry. J. Archaeol. Sci. 1998, 25, 259-270. [CrossRef]

15. Guerra, M.F. Analysis of Archaeological Metals. The Place of XRF and PIXE in the Determination of Technology and Provenance. X-ray Spectrom. Int. J. 1998, 27, 73-80. [CrossRef]

16. Hall, M.E. Pottery production during the Late Jomon period: Insights from the chemical analyses of Kasori B pottery. J. Archaeol. Sci. 2004, 31, 1439-1450. [CrossRef]

17. Charlton, M.F.; Crew, P.; Rehren, T.; Shennan, S.J. Explaining the evolution of ironmaking recipes-An example from northwest Wales. J. Anthr. Archaeol. 2010, 29, 352-367. [CrossRef]

18. Iñañez, J.G.; Buxeda, I.; Garrigós, J.; Speakman, R.J.; Glascock, M.D.; Suárez, E.S. Characterization of 15th-16th century majolica pottery found on the Canary Islands. Archaeological Chemistry: Analytical Methods and Archaeological Interpretation. In Proceedings of the ACS Symposium Series; American Chemical Society: Washington, DC, USA, 2007; Volume 968, pp. 376-398.

19. Speakman, R.J.; Little, N.C.; Creel, D.; Miller, M.R.; Iñañez, J.G. Sourcing ceramics with portable XRF spectrometers? A comparison with INAA using Mimbres pottery from the American Southwest. J. Archaeol. Sci. 2011, 38, 3483-3496. [CrossRef]

20. Forster, N.; Grave, P.; Vickery, N.; Kealhofer, L. Non-destructive analysis using PXRF: Methodology and application to archaeological ceramics. X-ray Spectrom. 2011, 40, 389-398. [CrossRef]

21. Goren, Y.; Mommsen, H.; Klinger, J. Non-destructive provenance study of cuneiform tablets using portable X-ray fluorescence (pXRF). J. Archaeol. Sci. 2011, 38, 684-696. [CrossRef]

22. Johnson, J. Accurate Measurements of Low Z Elements in Sediments and Archaeological Ceramics Using Portable X-ray Fluorescence (PXRF). J. Archaeol. Method Theory 2014, 21, 563-588. [CrossRef]

23. Hunt, A.M.W.; Speakman, R.J. Portable XRF analysis of archaeological sediments and ceramics. J. Archaeol. Sci. 2015, 53, 626-638. [CrossRef]

24. Holmqvist, E. Handheld Portable Energy-Dispersive X-Ray Fluorescence Spectrometry (pXRF). In The Oxford Handbook of Archaeological Ceramic Analysis; Oxford University Press: Oxford, UK, 2016; pp. 362-381. 
25. Liritzis, I.; Zacharias, N. Portable XRF of archaeological artifacts: Current research, potentials and limitations. In X-ray Fluorescence Spectrometry (XRF) in Geoarchaeology; Springer: Berlin/Heidelberg, Germany, 2011; pp. 109-142, ISBN 9781441968852.

26. Tykot, R.H.; White, N.M.; Du Vernay, J.P.; Freeman, J.S.; Hays, C.T.; Koppe, M.; Hunt, C.N.; Weinstein, R.A.; Woodward, D.S. Advantages and disadvantages of pXRF for archaeological ceramic analysis: Prehistoric pottery distribution and trade in NW Florida. In Archaeological Chemistry VIII; ACS Symposium Series; ACS Publications: Washington, DC, USA, 2013; Volume 1147, pp. 233-244.

27. Frahm, E.; Doonan, R.C.P. The technological versus methodological revolution of portable XRF in archaeology. J. Archaeol. Sci. 2013, 40, 1425-1434. [CrossRef]

28. Shugar, A.N.; Mass, J.L. Handheld XRF for Art and Archaeology; Leuven University Press: Leuven, Belgium, 2012; ISBN 9789461660695.

29. Shugar, A.N. Portable X-ray fluorescence and archaeology: Limitations of the instrument and suggested methods to achieve desired results. In Proceedings of the ACS Symposium Series. Am. Chem. Soc. 2013, 1147, 173-193.

30. Ceccarelli, L.; Rossetti, I.; Primavesi, L.; Stoddart, S. Non-destructive method for the identification of ceramic production by portable X-rays Fluorescence (pXRF). A case study of amphorae manufacture in central Italy. J. Archaeol. Sci. Rep. 2016, 10, 253-262. [CrossRef]

31. Aimers, J.J.; Farthing, D.J.; Shugar, A.N. Handheld XRF analysis of Maya ceramics: A pilot study presenting issues related to quantification and calibration. In Handheld XRF for Art and Archaeology; Leuven University Press: Leuven, Belgium, 2012; pp. 423-448, ISBN 9789461660695.

32. Speakman, R.J.; Shackley, M.S. Silo science and portable XRF in archaeology: A response to Frahm. J. Archaeol. Sci. 2013, 40, 1435-1443. [CrossRef]

33. Conrey, R.M.; Goodman-Elgar, M.; Bettencourt, N.; Seyfarth, A.; Van Hoose, A.; Wolff, J.A. Calibration of a portable X-ray fluorescence spectrometer in the analysis of archaeological samples using influence coefficients. Geochem. Explor. Environ. Anal. 2014, 14, 291-301. [CrossRef]

34. Ceccarelli, L. Production and Trade in Central Italy in the Roman Period: The Amphora Workshop of Montelabate in Umbria. Pap. Br. Sch. Rome 2017, 85, 109-141. [CrossRef]

35. Craig, N.; Speakman, R.J.; Popelka-Filcoff, R.S.; Glascock, M.D.; Robertson, J.D.; Shackley, M.S.; Aldenderfer, M.S. Comparison of XRF and PXRF for analysis of archaeological obsidian from southern Perú. J. Archaeol. Sci. 2007, 34, 2012-2024. [CrossRef]

36. Shackley, M.S. An introduction to X-ray fluorescence (XRF) analysis in archaeology. In X-ray Fluorescence Spectrometry (XRF) in Geoarchaeology; Springer: Berlin/Heidelberg, Germany, 2011; pp. 7-44, ISBN 9781441968852.

37. Goodale, N.; Bailey, D.G.; Jones, G.T.; Prescott, C.; Scholz, E.; Stagliano, N.; Lewis, C. PXRF: A study of inter-instrument performance. J. Archaeol. Sci. 2012, 39, 875-883. [CrossRef]

38. Frahm, E. Ceramic studies using portable XRF: From experimental tempered ceramics to imports and imitations at Tell Mozan, Syria. J. Archaeol. Sci. 2018, 90, 12-38. [CrossRef]

39. Shackley, M.S. Portable X-ray fluorescence spectrometry (pXRF): The good, the bad, and the ugly. Archaeol. Southwest Mag. 2012, 26, 1-8.

40. Papachristodoulou, C.; Gravani, K.; Oikonomou, A.; Ioannides, K. On the provenance and manufacture of red-slipped fine ware from ancient Cassope (NW Greece): Evidence by X-ray analytical methods. J. Archaeol. Sci. 2010, 37, 2146-2154. [CrossRef]

41. Gajić-Kvaščev, M.D.; Marić-Stojanović, M.D.; Jančić-Heinemann, R.M.; Kvaščev, G.S.; Andrić, V.D. Non-destructive characterisation and classification of ceramic artefacts using pEDXRF and statistical pattern recognition. Chem. Cent. J. 2012, 6, 102. [CrossRef] [PubMed]

42. López-García, P.; Argote-Espino, D.; Fačevicová, K. Statistical processing of compositional data. The case of ceramic samples from the archaeological site of Xalasco, Tlaxcala, Mexico. J. Archaeol. Sci. Rep. 2018, 19, 100-114. [CrossRef]

43. Baxter, M.J.; Buck, C.E. Data handling and statistical analysis. In Modern Analytical Methods in Art and Archaeology; Wiley: Hoboken, NJ, USA, 2000; pp. 681-746.

44. Aitchison, J.; Barceló-Vidal, C.; Pawlowsky-Glahn, V. Some comments on compositional data analysis in archaeometry, in particular the fallacies in Tangri and Wright's dismissal of logratio analysis. Archaeometry 2002, 44, 295-304. [CrossRef]

45. Filzmoser, P.; Hron, K.; Reimann, C. Principal component analysis for compositional data with outliers. Off. J. Int. Environ. Soc. 2009, 20, 621-632. [CrossRef]

46. Bergman, J.; Lindahl, A. Optimising archaeologic ceramics h-XRF analyses. In International Workshop on Compositional Data Analysis; Springer: Cham, Switzerland, 2016.

47. Mauran, G.; Caron, B.; Détroit, F.; Nankela, A.; Bahain, J.-J.; Pleurdeau, D.; Lebon, M. Data pretreatment and multivariate analyses for ochre sourcing: Application to Leopard Cave (Erongo, Namibia). J. Archaeol. Sci. Rep. 2021, 35, 102757. [CrossRef]

48. Baxter, M.J.; Freestone, I.C. Log-ratio compositional data analysis in Archaeometry. Archaeometry 2006, 48, 511-531. [CrossRef]

49. Tanasi, D.; Tykot, R.H.; Pirone, F.; McKendry, E. Provenance study of prehistoric ceramics from sicily: A comparative study between pXRF and XRF. Open Archaeol. 2017, 3, 222-234. [CrossRef]

50. Iserlis, M.; Steiniger, D.; Greenberg, R. Contact between first dynasty Egypt and specific sites in the Levant: New evidence from ceramic analysis. J. Archaeol. Sci. Rep. 2019, 24, 1023-1040. [CrossRef]

51. Tite, M.S. Ceramic production, provenance and use A review. Archaeometry 2008, 50, 216-231. [CrossRef]

52. Speakman, R.J.; Neff, H. Laser Ablation ICP-MS in Archaeological Research; UNM Press: Albuquerque, NM, USA, 2005. 
53. Odelli, E.; Selvaraj, T.; Perumal, J.; Palleschi, V.; Legnaioli, S.; Raneri, S. Pottery production and trades in Tamil Nadu region: New insights from Alagankulam and Keeladi excavation sites. Herit. Sci. 2020, 8, 56. [CrossRef]

54. Borges, C.S.; Weindorf, D.C.; Nascimento, D.C.; Curi, N.; Guilherme, L.R.G.; Carvalho, G.S.; Ribeiro, B.T. Comparison of portable $\mathrm{X}$-ray fluorescence spectrometry and laboratory-based methods to assess the soil elemental composition: Applications for wetland soils. Environ. Technol. Innov. 2020, 19, 100826. [CrossRef]

55. Montana, G. Ceramic raw materials: How to recognize them and locate the supply basins-Mineralogy, petrography. Archaeol. Anthropol. Sci. 2020, 12, 175. [CrossRef]

56. Cantini, F.; Grassi, F. Produzione, circolazione e consumo della ceramica in Toscana tra la fine del X e il XIII secolo. In Proceedings of the S. Gelichi (a cura di), Atti del IX Congresso Internazionale sulla ceramica medievale nel Mediterraneo, Venezia, Italy, 22-27 October 2012; pp. 131-140.

57. Basile, L.; Grassi, F.; Riccardi, M.P. Basso Gli scarichi di fornace di Roccastrada (Gr): Nuove analisi archeologiche ed archeometriche. In LRCW3 Late Roman Coarse Wares; Menchelli, S., Santoro, S., Pasquinucci, M., Guiducci, G., Eds.; BAR: Oxford, UK, 2011; p. S2185.

58. Grassi, F. Production, consumption and political complexity: Early Medieval pottery in Castile and southern Tuscany (7th-10th centuries). In Social Complexity in Early Medieval Rural Communities. The North-Western Iberia Archaeological Record; Archaeopress: Oxford, UK, 2016; pp. 91-112.

59. Fornacelli, C.; Briano, A.; Chiarantini, L.; Bianchi, G.; Benvenuti, M.; Giamello, M.; Kang, J.S.; Villa, I.M.; Talarico, F.M.; Hodges, R. Archaeometric Provenance Constraints for Early Medieval Sparse Glazed Pottery from Donoratico (Livorno, Italy). Archaeometry 2021, 63, 549-576. [CrossRef]

60. Ponta, E. Il Paesaggio e le sue Trasformazioni tra IV e VIII sec d.C. tra Costa ed Entroterra. Il Caso Della Toscana Centro Meridionale; University of Pisa: di Pisa, Italy, 2019.

61. Russo, L. Ceramica Grezza, Depurata e Semidepurata: Produzione, Funzione e Circolazione in un Territorio Della Toscana Sud-Occidentale; Colline Metallifere e territori limitrofi tra VIII- e XI secolo; Università degli Studi di Siena: Siena, Italy, 2021.

62. Grassi, F. Gli Apparati Produttivi, i Mercati ed il Consumo Della Ceramica Nella TOscana Meridionale (VIII-XIV secolo): Il Confronto Tra i Siti Rurali ed Urbani; Università degli Studi di Siena: Siena, Italy, 2005.

63. Vaccaro, E. Sites and Pots: Settlement and Economic Patterns in Southern Tuscany (AD 300-900); Archaeopress: Oxford, UK, 2012.

64. Bianchi, G. Analyzing fragmentation in the Early Middle Ages: The Tuscan model and the countryside in central-northern Italy. In New Directions in Early Medieval European Archaeology: Spain and Italy Compared; Brepols: Turnhout, Belgium, 2015; pp. 301-334.

65. Marasco, L. Un castello di pianura in località Vetricella a Scarlino (Scarlino Scalo, GR): Indagini preliminari e saggi di verifica. In P. FAVIA, G. VOLPE (a cura di), V Congresso Nazionale di Archeologia Medievale; Favia, P., Volpe, G., Eds.; University of Siena: Siena, Italy, 2009; pp. 326-331.

66. Carmignani, L.; Conti, P.; Cornamusini, G.; Meccheri, L. The internal Northern Apennines, the northern Tyrrhenian Sea and the Sardinia-Corsica block. Geol. Italy Spec. Vol. Ital. Geol. Soc. IGC 2004, 32, 59-77.

67. Gianelli, G.; Manzella, A.; Puxeddu, M. Crustal models of the geothermal areas of southern Tuscany (Italy). Tectonophysics 1997, 281, 221-239. [CrossRef]

68. Brunet, C.; Monié, P.; Jolivet, L.; Cadet, J.-P. Migration of compression and extension in the Tyrrhenian Sea, insights from 40Ar/39Ar ages on micas along a transect from Corsica to Tuscany. Tectonophysics 2000, 321, 127-155. [CrossRef]

69. Dini, A.; Gianelli, G.; Puxeddu, M.; Ruggieri, G. Origin and evolution of Pliocene-Pleistocene granites from the Larderello geothermal field (Tuscan Magmatic Province, Italy). Lithos 2005, 81, 1-31. [CrossRef]

70. Viti, C.; Lupieri, M.; Reginelli, M. Weathering sequence of rhyolitic minerals: The kaolin deposit of Torniella (Italy). Neues Jahrb. Für Miner.-Abh. 2007, 183, 203-213. [CrossRef]

71. Lattanzi, P.; Benvenuti, M.; Costagliola, P.; Tanelli, G. An overview on recent research on the metallogeny of Tuscany, with special reference to Apuane Alps. Mem. Della Soc. Geol. Ital. 1994, 48, 613-625.

72. Bonciani, F.; Callegari, I.; Conti, P.; Cornamusini, G.; Carmignani, L. Neogene post-collisional evolution of the internal Northern Apennines: Insights from the upper Fiora and Albegna valleys (Mt. Amiata geothermal area, southern Tuscany). Boll. Della Soc. Geol. Ital. 2005, 3, 103-118.

73. Bossio, A.; Costantini, A.; Foresi, L.M.; Lazzarotto, A.; Mazzanti, R.; Mazzei, R.; Pascucci, V.; Salvatorini, G.; Sandrelli, F.; Terzuoli, A.; et al. Neogene-Quaternary sedimentary evolution in the western side of the Northern Apennines (Italy). Mem. Della Soc. Geol. Ital. 1998, 52, 513-525.

74. Lattanzi, P.; Benvenuti, M.; Costagliola, P.; Maineri, C.; Mascaro, I.; Tanelli, G.; Dini, A.; Ruggieri, G. Magmatic versus hydrothermal processes in the formation of raw ceramic material deposits in Southern Tuscany. In Proceedings of the Tenth International Symposium On Water-Rock Interaction, Villasimius, Italy, 10-15 July 2001; pp. 725-728.

75. Stoltman, J.B. The Role of Petrography in the Study of Archaeological Ceramics. In Earth Sciences and Archaeology; Springer: Boston, MA, USA, 2001; pp. 297-326.

76. Courty, M.A.; Goldberg, P.; Macphail, R.I. Soil micromorphology in archaeology. Endeavour 1990, 14, 163-171. [CrossRef]

77. Killick, D. The awkward adolescence of archaeological science. J. Archaeol. Sci. 2015, 56, 242-247. [CrossRef]

78. Hein, A. Revisiting the groups: Exploring the feasibility of portable EDXRF in provenance studies of transport amphorae in the Eastern Aegean. In Application of Portable Energy-Dispersive X-ray Fluorescence to the Analysis of Archaeological Ceramics and Glass. Topoi. Berlin Studies of the Ancient World; Peking University Press: Beijing, China, 2017. 
79. Hein, A.; Dobosz, A.; Day, P.M.; Kilikoglou, V. Portable ED-XRF as a tool for optimizing sampling strategy: The case study of a Hellenistic amphora assemblage from Paphos (Cyprus). J. Archaeol. Sci. 2021, 133, 105436. [CrossRef]

80. Kenna, T.C.; Nitsche, F.O.; Herron, M.M.; Mailloux, B.J.; Peteet, D.; Sritrairat, S.; Sands, E.; Baumgarten, J. Evaluation and calibration of a Field Portable X-Ray Fluorescence spectrometer for quantitative analysis of siliciclastic soils and sediments. J. Anal. At. Spectrom. 2011, 26, 395-405. [CrossRef]

81. Walton, M.S. Materials Chemistry Investigation of Archaeological Lead Glazes; University of Oxford: Oxford, UK, 2004.

82. Téreygeol, F.; Henning, J. Production and circulation of silver and secondary products (lead and glass) from Frankish royal silver mines at Melle (eighth to tenth century). In Volume 1 The Heirs of the Roman West; Walter de Gruyter: Berlin, Germany, 2007; Volume 5, p. 123.

83. Niederschlag, E.; Pernicka, E.; Seifert, T.; Bartelheim, M. The Determination of Lead Isotope Ratios by Multiple Collector Icp-Ms: A Case Study of Early Bronze Age Artefacts and their Possible Relation With Ore Deposits of the Erzgebirge. Archaeometry 2003, 45, 61-100. [CrossRef]

84. Asmus, B. Medieval Copper Smelting in the Harz Mountains, Germany; University College London: London, UK, 2011.

85. Costa, V.; Urban, F. Lead and its alloys: Metallurgy, deterioration and conservation. Stud. Conserv. 2005, 50, 48-62. [CrossRef]

86. Salminen, R. Geochemical Atlas of Europe; Geological Survey of Finland: Espoo, Finland, 2005.

87. Glascock, M. Characterization of Archaeological Ceramics at MURR by Neutron Activation Analysis and Multivariate Statistics. In Chemical Characterization of Ceramic Pastes in Archaeology; Neff, H., Ed.; Prehistory Press: Madison, WI, USA, $1992 ;$ pp. 11-26.

88. Baxter, M.J.; Cool, H.E.M.; Heyworth, M.P.; Jackson, C. Compositional Variability in Colourless Roman Vessel Glass. Archaeometry 1995, 37, 129-141. [CrossRef]

89. Aitchison, J. Logratios and natural laws in compositional data analysis. Math. Geol. 1999, 31, 563-580. [CrossRef]

90. Beardah, C.C.; Baxter, M.J.; Cool, H.E.M.; Jackson, C.M. Compositional Data Analysis of Archaeological Glass: Problems and Possible solutions. In Proceedings of the Compositional Data Analysis Workshop, CODAWORK, Girona, Spain, 15-17 October 2003; pp. 279-300.

91. Simsek Franci, G. Handheld X-ray Fluorescence (XRF) Versus Wavelength Dispersive XRF: Characterization of Chinese Blue-andWhite Porcelain Sherds Using Handheld and Laboratory-Type XRF Instruments. Appl. Spectrosc. 2020, 74, 314-322. [CrossRef]

92. Demirsar Arli, B.; Simsek Franci, G.; Kaya, S.; Arli, H.; Colomban, P. Portable X-ray Fluorescence (p-XRF) Uncertainty Estimation for Glazed Ceramic Analysis: Case of Iznik Tiles. Heritage 2020, 3, 1302-1329. [CrossRef]

93. Kuleff, I.; Djingova, R. Provenance study of pottery; choice of elements to be determined. ArchéoSci. Rev. D'archéom. 1996, 20, 57-67. [CrossRef]

94. Annis, M.B. Ceramica altomedievale a vetrina pesante e ceramica medievale a vetrina sparsa proveniente dallo scavo di San Sisto Vecchio in Roma: Analisi tecnologica e proposta interpretativa. In Proceedings of the Ceramica Invetriata Tardoantica e Altomedievale in Italia, Atti del Seminario, Siena, Italy, 23-24 February 1990; pp. 394-417.

95. Sfrecola, S. La ceramica a vetrina pesante (Forum Ware) e la ceramica a vetrina sparsa da alcuni siti nella Campagna Romana. In Proceedings of the Ceramica Invetriata Tardoantica e Altomedievale in Italia, Atti del Seminario, Siena, Italy, 23-24 February 1990; pp. 562-579.

96. Tassi, E.; Grifoni, M.; Bardelli, F.; Aquilanti, G.; La Felice, S.; Iadecola, A.; Lattanzi, P.; Petruzzelli, G. Evidence for the natural origins of anomalously high chromium levels in soils of the Cecina Valley (Italy). Environ. Sci. Process. Impacts 2018, 20, 965-976. [CrossRef] [PubMed]

97. Vaccaro, E. Long-distance ceramic connections: Portus Scabris (Portiglioni, GR), coastal tuscany and the Tyrrhenian Sea. In Origins of a New Economic Union (7th-12th Centuries). Preliminary Results of the nEU-Med Project (October 2015-March 2017); All'Insegna del Giglio: Firenze, Italy, 2018; pp. 81-99. 